\title{
Inhibition of Methicillin-resistant Staphylococcus aureus-induced cytokines mRNA production in human bone marrow derived mesenchymal stem cells by 1,25 -dihydroxyvitamin $D_{3}$
}

Aparna Maiti ${ }^{*}$ and William A Jiranek ${ }^{2}$

\begin{abstract}
Background: Methicillin-resistant Staphylococcus aureus (MRSA) is the predominant cause of bone infection. Toll like receptors (TLRs) are an important segments of host response to infection and are expressed by a variety of cells including human mesenchymal stem cells (hMSCs). The active form of Vitamin D, 1,25-dihydroxyvitamin D3 $\left(1,25(\mathrm{OH})_{2} \mathrm{D}_{3}\right)$ has potent immunoregulatory properties, but the mechanism remains poorly understood. The genomic action of $1,25(\mathrm{OH})_{2} \mathrm{D}_{3}$ is mediated by vitamin $\mathrm{D}$ receptor $(\mathrm{VDR})$, hormone-regulated transcription factor. VDR interacts with co-activators and co-repressors are associated with chromatin histone modifications and transcriptional regulation. The aim of our study is to explore MRSA-induced TLRs-mediated pro-inflammatory cytokines expression in hMSCs. Further, we hypothesized that $1,25(\mathrm{OH})_{2} \mathrm{D}_{3}$ inhibits MRSA-induced cytokines synthesis in hMSCs via inhibition of NF-KB transcription factor. Finally, we explored the regulatory role of $1,25(\mathrm{OH})_{2} \mathrm{D}_{3}$ in MRSA-mediated global epigenetic histone $\mathrm{H} 3$ mark, such as, trimethylated histone $\mathrm{H} 3$ lysine 9 (H3K9me3), which is linked to gene silencing.

Results: Quantitative PCR data revealed that MRSA-infection predominantly induced expression of TLRs 1, 2, 6, NR4A2, and inflammatory cytokines IL-8, IL-6, TNFa in hMSCs. MRSA-mediated TLR ligands reduced osteoblast differentiation and increased hMSCs proliferation, indicating the disrupted multipotency function of hMSCs. Pretreatment of $1,25(\mathrm{OH})_{2} \mathrm{D}_{3}$ followed by MRSA co-culture inhibited nuclear translocation of NF-kB-p65, reduced expression of NR4A2 and pro-inflammatory cytokines IL-8, IL-6, and TNFa in hMSCs. Further, NF-kB-p65, VDR, and NR4A2 were present in the same nuclear protein complex, indicating that VDR is an active part of the nuclear protein complexes for transcriptional regulation. Finally, $1,25(\mathrm{OH})_{2} \mathrm{D}_{3}$ activated VDR, restores the global level of H3K9me3, to repress MRSA-stimulated inflammatory cytokine IL-8 expression. Pretreatment of 5-dAZA, DNA methylatransferases (Dnmts) inhibitor, dramatically re-expresses 1,25(OH) ${ }_{2} \mathrm{D}_{3}$-MRSA-mediated silenced IL-8 gene.

Conclusions: This data indicates that TLR 1, 2, and 6 can be used as markers for localized S. aureus bone infection. $1,25(\mathrm{OH})_{2} \mathrm{D}_{3}$-VDR may exhibits its anti-inflammatory properties in MRSA-stimulated infection by inhibiting nuclear translocation of NF-kB-p65 and transcripts of IL-8, IL-6, TNFa, and NR4A2 in hMSCs. Finally, 1,25(OH) ${ }_{2} \mathrm{D}_{3}$-activated VDR, acting as an epigenetic regulator, inhibits synthesis of cytokines in MRSA-stimulated infection by restoring the global level of H3K9me3, a histone H3 mark for gene silencing.
\end{abstract}

Keywords: Toll like receptors (TLRS), Methicillin-resistant Staphylococcus aureus (MRSA), Human Mesenchymal Stem Cells (hMSCs), Osteogenesis, 1,25(OH) ${ }_{2} \mathrm{D}_{3}$ (Vitamin D), Interleukin 8 (IL-8), Infection, Chronic inflammation, Histone methylation

\footnotetext{
* Correspondence: amaiti2@vcu.edu

${ }^{1}$ Department of Orthopaedic Surgery, Orthopaedic Research Laboratory, 1112

East Clay Street, Richmond, USA

Full list of author information is available at the end of the article
}

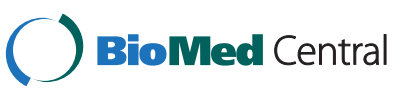

(c) 2014 Maiti and Jiranek; licensee BioMed Central Ltd. This is an Open Access article distributed under the terms of the Creative Commons Attribution License (http://creativecommons.org/licenses/by/2.0), which permits unrestricted use, distribution, and reproduction in any medium, provided the original work is properly credited. The Creative Commons Public Domain Dedication waiver (http://creativecommons.org/publicdomain/zero/1.0/) applies to the data made available in this article, unless otherwise stated. 


\section{Background}

Staphylococci, in particular Methicillin-resistant Staphylococcus aureus (MRSA), are the predominant cause of bone and joint infection. These infections cause serious morbidity and are often difficult to treat [1]. Recent evidence demonstrates that bacterially infected osteoblasts secrete chemokines and cytokines, suggesting that these cells are playing important role in combating localized infection through inflammation [2,3]. The goal of this study was to evaluate MRSA infection mediated host responses, and the molecular mechanisms of host defenses. Human Bone marrow derived mesenchymal stem cells (hMSCs) are known to support hematopoiesis to regenerate bone, cartilage and adipose tissues. Thus hMSCs possess complex biological functions which maintain the microenvironment of bone marrow. In addition, hMSCs are well known for their immunoregulatory characteristics [4]. They express pattern recognition receptors (PRRs) which recognize pathogenic molecules. The PRRs found in hMSCs are Toll like receptors (TLRs) [4]. There are currently 11 known mammalian TLRs of which TLR1-10 are functional in humans [5]. TLRs are the family of conserved transmembrane receptors, which are expressed by a variety of immune cells, and non-immune cells including mesenchymal stem cells. TLRs recognize several conserved PRRs like triacylated lipoprotein (TLR1 and TLR2), diacylated lipoprotein (TLR2, TLR6), double stranded RNA (TLR3), lipopolysaccharide (TLR4), flagellin (TLR5), single stranded RNA (TLR8) and unmethylated DNA (TLR9) as well as viral and bacterial nucleic acids [6-8]. Activation of TLR by its ligand results in several biological outcomes ranging from secretion of cytokines, rapid cellular differentiation, apoptosis, and up regulation of antimicrobial activity [9-11]. Thus in the present study, we have used hMSCs as our cell model to survey the expression of all known TLRs in response to MRSA co-culture condition which increased inflammation. Activation of TLRs with MRSA ligands predominantly increased TLR 1, 2 and 6 expression including transcription factor NR4A2, and pro-inflammatory cytokines e.g. IL-8, IL-6 and TNF $\alpha$ that altered normal function of hMSCs cell biology.

The active form of vitamin $\mathrm{D}, 1,25(\mathrm{OH})_{2} \mathrm{D}_{3}$, the secosteroid hormone that is well known for calcium homeostasis. The genomic action of this hormone is mediated by nuclear receptor-vitamin $\mathrm{D}$ receptor (VDR). $1,25(\mathrm{OH})_{2} \mathrm{D}_{3}$ deficiency causes rickets in children and osteomalacia in adults. Low $1,25(\mathrm{OH})_{2} \mathrm{D}_{3}$ is also linked to increased disease activity in rheumatoid arthritis, and increased susceptibility to bacterial infection [12-14]. In addition TLR activation in human monocytes results in expression of the vitamin $\mathrm{D}$ receptor and vitamin $\mathrm{D}$ hydroxylase (cyp27B1) and antimicrobial peptide cathelicidin expression that has direct antimicrobial activity against
M. tuberculosis when co-incubated with the bacteria [15]. Like other nuclear receptors, VDR interacts with coactivators and co-repressors during the transcriptional cycle, and these interactions combine to determine histone modifications [16-18]. Thus it is well established that 1,25 $(\mathrm{OH})_{2} \mathrm{D}_{3}$ is an important modulator of immune system. However, the precise molecular mechanisms that are regulated by VDR following TLR induction are not well defined. In the present study, we sought to examine the ability of $1,25(\mathrm{OH})_{2} \mathrm{D}_{3}$ to modulate the MRSA mediated inflammatory response in hMSCs. $1,25(\mathrm{OH})_{2} \mathrm{D}_{3}$ treatment followed by MRSA co-culture inhibit nuclear translocation of NF-кB-p65 and reduced cytokines (IL-6, IL-8, and TNF $\alpha$ ) and NR4A2 expressions in hMSCs. Finally, $1,25(\mathrm{OH})_{2} \mathrm{D}_{3}$ activated VDR restores the global level of H3K9me3 to repress MRSA-stimulated inflammatory cytokine IL-8 expression. In addition, 5-dAZA, an inhibitor of DNA methylatransferases, reduces DNA and histone methylation, enhances IL-8 gene expression, furthermore, it dramatically re-expresses the $1,25(\mathrm{OH})_{2} \mathrm{D}_{3}$ MRSA-mediated silenced IL-8 gene.

\section{Results}

Methicillin-resistant Staphylococcus aureus (MRSA)-infection predominantly induces TLRs 1, 2, and 6 expressions in hMSCs In order to understand the differential TLRs members activated in hMSCs due to MRSA infection, we treated in vitro cultured adherent hMSCs with live MRSA as described in Materials and Methods. The TLRs mRNA expression pattern was analyzed by semi quantitative RTPCR, using validated human specific primers of TLR1-9 in response to co-cultured with or without MRSA in hMSCs. We used in vitro cultured hMSCs without any bacterial infection as our control treatment. Three independent PCR run were done with hMSCs isolated from three independent donors to check consistency of the TLR expression in control cells, before doing MRSA co-culture as treatment. As shown in Figure 1, the expression levels of TLR3, TLR4 and TLR5 mRNAs in control hMSCs (without co-culture with live MRSA) were consistently high. By contrast, low expression level of TLR1, TLR2 and TLR6 and no expression of TLR 7, TLR 8, and TLR 9 were detected in control hMSCs, similar with the results obtained by Liotta et al. [19]. By contrast, we found that co-culture with live MRSA increased expression level of TLR1, TLR2, and TLR6 (Figure 1A). We used U937 human macrophage cells as positive control for human TLRs mRNA expressions with the same set of primers. The semi quantitative RT-PCR results of TLR mRNA expressions (Figure 1A) were further confirmed by quantitative real time PCR (qPCR) (Figure 1B). Furthermore, MRSA treatment in hMSCs also induced TLR proteins as confirmed western blotting (Figure 1C). When TLRs are activated by its ligands in hMSCs, it leads to activation of 

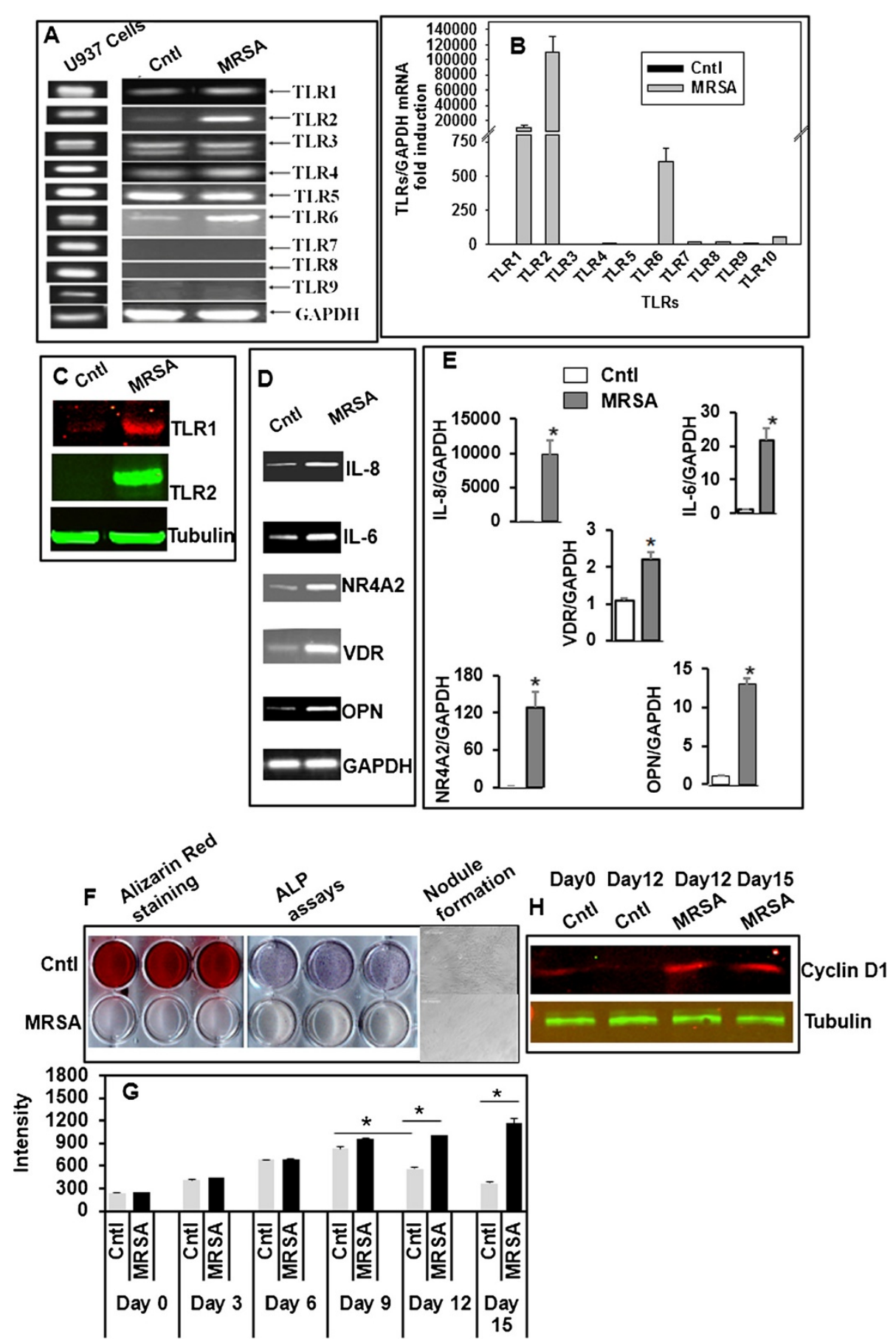

Figure 1 (See legend on next page.) 
(See figure on previous page.)

Figure 1 MRSA co-culture induces TLRs expression by hMSCs. Human MSCs total RNA was subjected to RT-PCR and qRT-PCR using SYBR green assay with TLRs specific primes. Representative RT-PCR of each TLR was shown. Human MSCs with no bacterial infection CDNA was used as control. U937 cell line cDNA was used as positive control for PCR amplification (A). GAPDH was used as a reference. The relative mRNA expression was determined by the delta-delta comparative threshold (ddCT) method. (B). TLR1 and TLR2 protein expression in MSCs are shown (C). Cytokines stimulation in hMSCs by MRSA. RT-PCR was done with human specific primers of IL-8, IL-6, NR4A2, VDR, osteopontin (OPN), and GAPDH as a control (D). RT-PCR data in hMSCs were further confirmed with qRT-PCR analysis using SYBR green assay, where GAPDH as an endogenous control (E). Data are from $n=3$ independent experiments done in triplicate. ${ }^{*} \mathrm{P}<0.05$ compared to control. MSCs were co-culture with and without S.aureus and cultured in osteogenic medium supplemented with dexamethasone (0.1 $1 \mu$ M). Alizarin Red staining was done at day 15. Alkaline phosphatase activity was measured at day 9 from cell lysate as released p-nitrophenol. At day 12, cells showed change in morphology and bone nodule formation in cultures of differentiating osteoblasts. Representative picture was shown. Original magnifications are 10x (F). Cells were incubated with DRAQ5 for 5 min followed by washing with PBS and scanned in Li-Cor Odyssey Infrared Scanner. Equal area scanned intensities were plotted against samples of different day of treatment (G). $n=3,{ }^{*} \mathrm{P}<0.002$ compared to control. Western blot analysis of Cyclin D1 using Day 12 and Day15 MRSA co-culture hMSCs protein extracts compared to Day 0, and Day 12 control extracts $(\mathbf{H})$.

several known inflammatory pathways, synthesize and secrete cytokines, chemokines, and growth factors. This activation can lead to changes of basic function of bone marrow derived mesenchymal stem cells [4]. In immune cells, TLR activation signal leads to secretion of a variety of pro-inflammatory cytokines [20,21]. We therefore hypothesized that MRSA mediated TLRs activation up regulate several inflammatory genes. We analyzed mRNA expression of several cytokines by qPCR analysis from unstimulated or MRSA stimulated hMSCs. In agreement with NF- $\mathrm{B}$ activation in response to co-culture with MRSA in MSCs, NF-kB-target pro-inflammatory cytokines IL-6, IL-8, and TNF $\alpha$ were significantly increased at the transcription level (Figure 1D-E), supporting similar data obtained by Lee et al. [20]. Figure 1D indicates that NR4A2 transcript is up regulated with 24 hrs of MRSA infection in hMSCs. This supports the clinical study that increased IL-8 and NR4A2 expression is also associated with the development and clinical symptoms of human inflammatory arthritis [22]. It was reported earlier that NR4A2 regulates the expression of various osteoblastic differentiation markers including osteopontin (OPN), a glycoprotein detected in several tissues in the body [23]. Interestingly, MRSA as TLR ligands stimulates OPN transcripts while no change in collagen type I transcripts (data not shown) were observed in hMSCs (Figure 1D-E). VDR is a nuclear receptor that mediates most known functions of $1,25(\mathrm{OH})_{2} \mathrm{D}_{3}$, the active form of vitamin $\mathrm{D}$ [24]. VDR forms heterodimers with RXR once VDR is activated by $1,25(\mathrm{OH})_{2} \mathrm{D}_{3}$. VDR binds to the vitamin $\mathrm{D}$ response element in the target gene promoter to regulate gene transcription [24]. Interestingly, RT-PCR data indicated that MRSA up regulated VDR in hMSCs (Figure 1D). Semi quantitative RT-PCR data (Figure 1D) were further confirmed by qPCR SYBR green assay (Figure 1E). Altogether our data indicated that TLR activation by MRSA play important roles in pathogenesis of these bacteria in hMSCs. It was reported earlier that TLRs and their ligands control murine MSCs function $[4,25]$. To examine whether MRSA as TLR ligand has any effect on in vitro cultured hMSCs biology, we co-cultured freshly isolated hMSCs with and without MRSA and allowed to differentiate in osteogenic medium containing dexamethasone for 15 days. In Figure 1F, control cells (without MRSA co-culture) at day 12 , strongly stimulated bone nodule formation with dexamethasone treatment as shown by microscopic representative image (magnification $10 \times)$. However, the presence of MRSA totally abolished hMSCs matrix calcification as measured by alizarin red staining and alkaline phosphatase (an osteogenic marker) assay. No nodule formation was observed in MRSA cocultured hMSCs (Figure 1F). Cell proliferation assay was done at every 3 days interval, with DRAQ5, a fluorescent dye that stain DNA inside the cells (Figure 1G). It was observed that, control cells stopped proliferating and started forming nodule after day 9, however, MRSA co-culture enhanced proliferation in hMSCs and failed to differentiate into osteoblasts until day 15 (Figure 1G). As expected, expression of cells proliferation marker cyclin D1 remains elevated until 12-15 days of MRSA infection in hMSCs compared to control as shown by western blot analysis (Figure $1 \mathrm{H}$ ). Thus, our data indicate the incomplete differentiation potential of hMSCs due to extracellular S. aureus infection.

\section{MRSA-induced nuclear NF-KB activity is inhibited by $1,25(\mathrm{OH})_{2} \mathrm{D}_{3}$ in hMSCs}

It has been shown that in immune cells, TLR activation is linked to activation of NF- $\mathrm{KB}$ dimer, a transcription factor consisting of p65 and p50 subunits, which enters the nucleus and regulates transcription of target genes $[20,26,27]$. In order to investigate whether TLRs expressed on hMSCs are functional, the outcome of TLR agonistsmediated TLR activation was performed using NF- $\mathrm{kB}$ nuclear localization by western blot as a read-out of its activation. Human MSCs were stimulated with MRSA as TLR ligands for increasing time points and subsequent nuclear and cytosolic fractionations studies were performed for western blot analysis for NF-kB-p65. In un-stimulated cells without any MRSA stimulation, 
NF-kB-p65 was localized mainly in cytoplasm (Figure 2A). As shown in Figure 2A-B, co-culture with MRSA induced NF-kB-p65 translocation to nucleus from cytosol within an hour and remains elevated in nucleus until $24 \mathrm{~h}$ of infection in hMSCs. This data further supporting the notion of functional status of TLRs signals which activate NF$\mathrm{kB}$ transcription factor in human bone marrow-derived MSCs. Reduced $1,25(\mathrm{OH})_{2} \mathrm{D}_{3}$ intake or $1,25(\mathrm{OH})_{2} \mathrm{D}_{3}$ deficiency linked to susceptibility to $S$. aureus infection. $1,25(\mathrm{OH})_{2} \mathrm{D}_{3}$ is also well established for inhibiting inflammatory signals by inhibiting NF- $\mathrm{B}$ activity in adipocytes [28]. In Figure $1 \mathrm{~B}$ we also observed that TLR activation by MRSA increased VDR transcript. So we further investigated the effect of $1,25(\mathrm{OH})_{2} \mathrm{D}_{3}$ on nuclear translocation of the p65 subunit of NF-kB by western blot analysis in hMSCs. Our data indicated that pretreatment of hMSCs with $100 \mathrm{nM}$ of $1,25(\mathrm{OH})_{2} \mathrm{D}_{3}$ for $72 \mathrm{hrs}$ followed by MRSA stimulation for $24 \mathrm{hrs}$ almost completely blocked NF-kB-p65 nuclear translocation (Figure 2C-D). To determine whether NF-kB-p65, VDR and NR4A2 could bind to the MRSA stimulated transcription complex in vivo, we performed immunoprecipitation assay. Human MSCs were stimulated with or without MRSA for $24 \mathrm{hrs}$ and nuclear protein was used to perform immunoprecipitation with NF-kB-p65 rabbit polyclonal antibody. Our data indicated that NF-kB-p65, VDR and NR4A2 were present in the same nuclear protein complex (Figure 2E), indicating that VDR is an active part of the nuclear protein complexes for transcriptional regulation [29].

\section{Inhibitory effect of $1,25(\mathrm{OH})_{2} \mathrm{D}_{3}$ on MRSA-stimulated} inflammatory cytokines mRNA expressions in hMSCs Interestingly, earlier studies have shown that $1,25(\mathrm{OH})$ ${ }_{2} \mathrm{D}_{3}$ can suppress the release of TNF- $\alpha$ [30], the expression of IL-8 in human periodontal ligament cells stimulated with Porphyromonas gingivalis, associated with chronic periodontitis [31], LPS-stimulated IL-6 protein and mRNA synthesis in two human adipocyte models via interference with $\mathrm{NF}-\mathrm{kB}$ signaling [28]. Moreover, $1,25(\mathrm{OH})_{2} \mathrm{D}_{3}$ effectively up-regulates the synthesis of the anti-inflammatory cytokine IL-10 and induces IL-10 receptor expression in vitro [32]. In contrast, $1,25(\mathrm{OH})_{2} \mathrm{D}_{3}$ deficiency increases TNF- $\alpha$ levels in healthy women [33]. In order to examine whether $1,25(\mathrm{OH})_{2} \mathrm{D}_{3}$ pretreatment down regulate MRSA-mediated inflammatory responses in hMSCs, we pretreated $100 \mathrm{nM}$ of $1,25(\mathrm{OH})_{2} \mathrm{D}_{3}$ for 24 , 48 and 72 hrs, followed by MRSA co-culture for another 24 hrs. Real-time quantitative PCR was performed with human specific primers of IL-8, IL-6, TNF- $\alpha$, NR4A2,

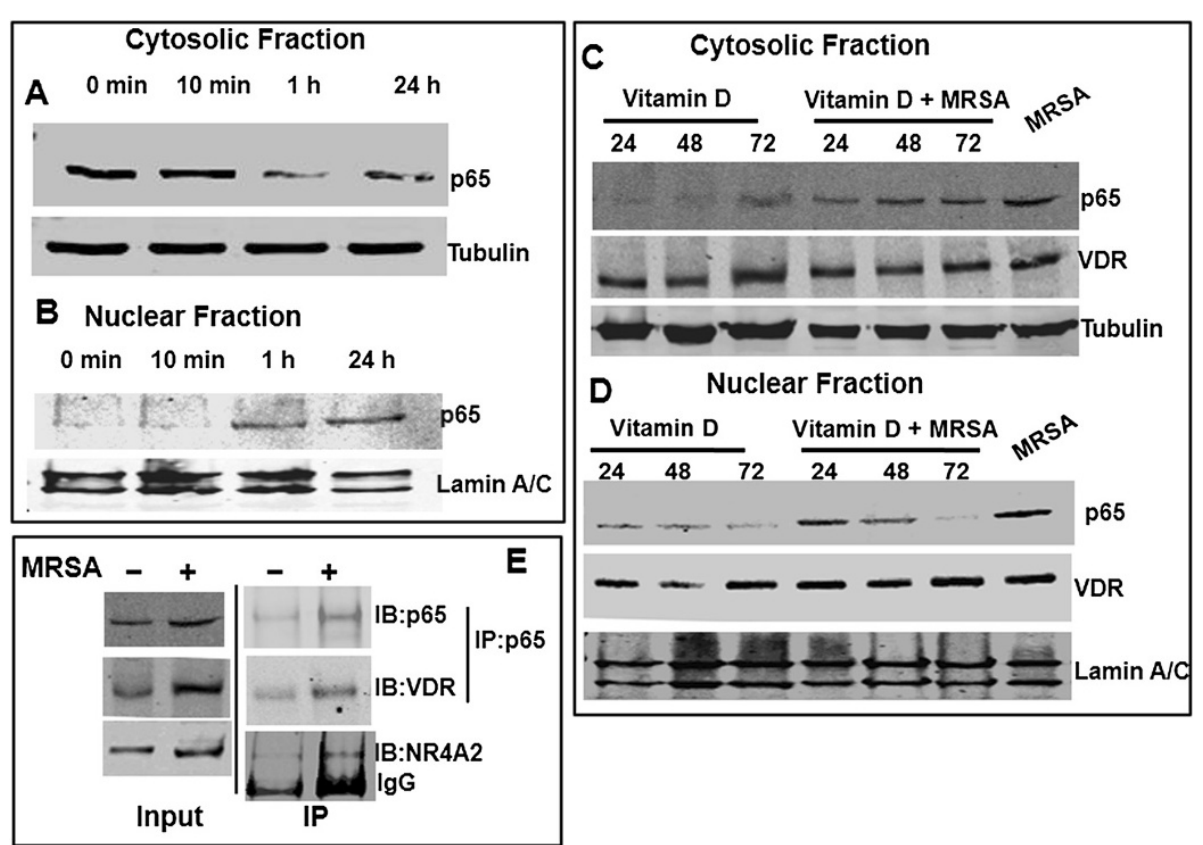

Figure 2 1,25(OH)2D3 blocks NF-KB signaling in MRSA-stimulated hMSCs. Human MSCs were co-culture with methicillin-resistant Staphylococcus aureus (MRSA) for $0 \mathrm{~min}, 10 \mathrm{~min}, 1 \mathrm{hr}$ and 24 hrs and harvested for cytopalsmic and nuclear proteins extraction. Equal amount of proteins were used for western blot analyses with indicated antibodies (A-B). Human MSCs were preincubated with vitamin D (100 nM) for 24, 48 and 72 hours, followed by methicillin-resistant Staphylococcus aureus (MRSA)-stimulation for 24 hours. Cytopalsmic and nuclear proteins were extracted for western blot analysis with indicated antibodies (C-D). Experiments were done three times and representative blots were shown. NF-KB-p65 present in nuclear protein complexes with VDR, and NR4A2 of hMSCs. Human MSCs were stimulated with or without methicillin-resistant Staphylococcus aureus (MRSA) for $24 \mathrm{hrs}$ and harvested for nuclear proteins extraction. Equal amount of proteins were used for immunoprecipitation (IP) with anti-NF-kB-p65 antibodies and immuno blots (IB) were done with indicated antibodies (E). Experiments were done three times and representative blots were shown. 
VDR, Cathelicidin using SYBR green assay. Our results showed that MRSA mediated inflammatory responses up regulated VDR expression (Figure 3A vi), furthermore, $1,25(\mathrm{OH})_{2} \mathrm{D}_{3}$ pretreatment inhibits MRSA-stimulated IL8, IL-6 transcripts in a time dependent manner (Figure 3A $\mathrm{i}$ and $3 \mathrm{~A}$ iii). TNF- $\alpha$ and NR4A2 transcripts are inhibited within 24 hrs of $1,25(\mathrm{OH})_{2} \mathrm{D}_{3}$ pretreatment (Figure 3A ii, $3 \mathrm{~A}$ iv). Pretreatment with $1,25(\mathrm{OH})_{2} \mathrm{D}_{3}$ followed by MRSA co-culture caused time dependent increase of cathelicidin transcript (Figure $3 \mathrm{~A} \mathrm{v}$ ). $1,25(\mathrm{OH})_{2} \mathrm{D}_{3}$ pretreatment to control hMSCs (without MRSA stimulation) has no effect on TNF- $\alpha$ and NR4A2 transcripts (Figure 3A ii, $3 \mathrm{~A}$ iv). Taken together, $1,25(\mathrm{OH})_{2} \mathrm{D}_{3}$ was able to significantly reduce MRSA-induced IL-8, IL-6, TNF- $\alpha$ and NR4A2 mRNA expressions in hMSCs. This effect was observed both at concomitant incubation with MRSA and $1,25(\mathrm{OH})_{2} \mathrm{D}_{3}$ together (data not shown) and pretreatment with $1,25(\mathrm{OH})_{2} \mathrm{D}_{3}$ followed by MRSA co-culture in hMSCs. Furthermore, MRSA infection in hMSCs induced many pro-inflammatory cytokines protein expression, such as TNF- $\alpha$, and IL-8, and their secretion into the culture medium (Figure 3B i-ii).

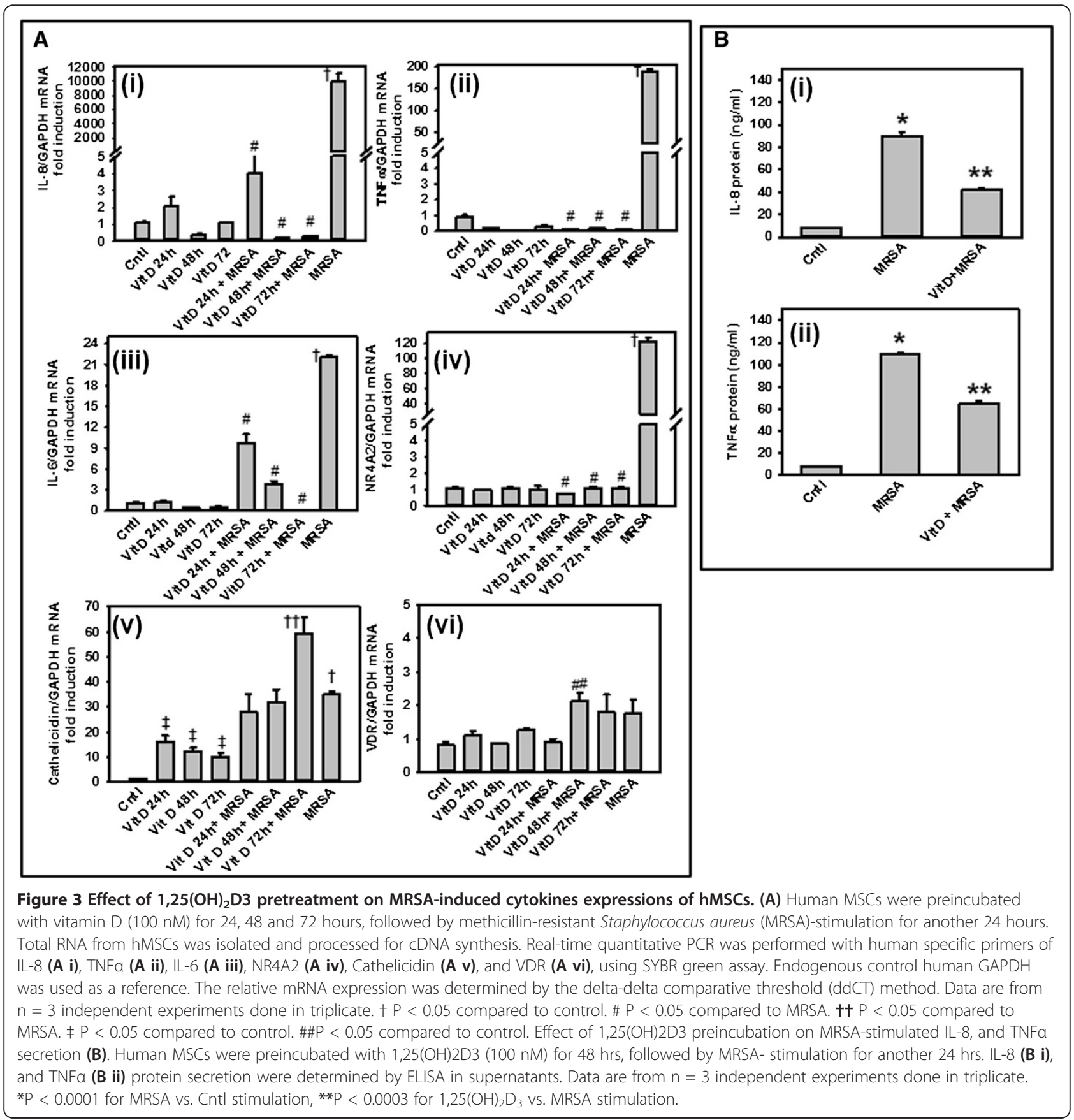


Interestingly, pretreatment with $1,25(\mathrm{OH})_{2} \mathrm{D}_{3}$ followed by MRSA co-culture in hMSCs significantly blocked secretion of IL-8, and TNF- $\alpha$ proteins (Figure 3i-3ii).

\section{$1,25(\mathrm{OH})_{2} \mathrm{D}_{3}$ affect the global level of histone $\mathrm{H} 3$ lysine 9 trimethylation ( $\mathrm{H} 3 \mathrm{~K} 9 \mathrm{me} 3)$ to repress MRSA-stimulated IL-8 transcription}

$1,25(\mathrm{OH})_{2} \mathrm{D}_{3}$, a hormonally active form of vitamin $\mathrm{D} 3$, is a repressive signal that binds to and activates the nuclear vitamin D receptor (VDR) [34,35]. A basic helix-loophelix transcriptional activator (VDR interacting repressor, VDIR) regulates the transcription of CYP27B1 by the negative $1,25(\mathrm{OH})_{2} \mathrm{D}_{3}$ response element (nVDRE) [36]. Heterodimers of $1,25(\mathrm{OH})_{2} \mathrm{D}_{3}$-bound VDR and retinoid $\mathrm{X}$ receptor (RXR) repress the activation of VDIR that is bound upon the nVDRE by means of the histone deacetylase (HDAC) co-repressor complex [37]. The DNA methyltrasferase (Dnmt1) interacted with both VDR and VDIR in a liganddependent manner. Indeed, treatment with $1,25(\mathrm{OH})_{2} \mathrm{D}_{3}$ induced DNA methylation at CpG sites in the promoter and exon regions of the CYP27B1 gene [38]. It has been shown that H3K9 methylation promotes DNA methylation and serve as a critical mark for DNA methylation and gene silencing $[39,40]$. Methylation of lysines H3K9 and H3K27 are correlated with transcriptional repression [41]. Particularly, H3K9me3 is highly correlated with constitutive heterochromatin [42]. Angrisano et al. [43] reported that LPS induces early histone H3 methylation and acetylation changes at the promoter region of IL- 8 gene in HT-29, a human intestinal epithelial cell line. Thus, $1,25(\mathrm{OH})_{2} \mathrm{D}_{3}$ may regulate expression of genes by epigenetic modifications of DNA and histones. In order to understand the molecular mechanisms how $1,25(\mathrm{OH})_{2} \mathrm{D}_{3}$ preincubation inhibiting inflammation, we tested effect of $1,25(\mathrm{OH})_{2} \mathrm{D}_{3}$, an active chromatin modulator, on the global level of histone $\mathrm{H} 3$ lysine 9 trimethylation (H3K9me3) in hMSCs, with or without MRSA-co-cultured conditions. Interestingly, we found that $1,25(\mathrm{OH})_{2} \mathrm{D}_{3}$ pretreatment alone or MRSA-stimulation alone remarkably reduces global level of $\mathrm{H} 3 \mathrm{~K} 9 \mathrm{me} 3$ compared to the control in hMSCs (Figure 4A). Furthermore, $1,25(\mathrm{OH})_{2} \mathrm{D}_{3}$ pretreatment followed by MRSA-stimulation restored global level of H3K9me3 compared to the control in hMSCs (Figure 4A). Acetylation of lysine 9 on histone $\mathrm{H} 3$ (H3K9ac) has been linked to gene activation and active transcription [44]. We have also tested the global level of H3K9ac in this condition in hMSCs cell extracts. Interestingly, we found that $1,25(\mathrm{OH})_{2} \mathrm{D}_{3}$ pretreatment alone doesn't affect the global level of H3K9ac, however, MRSA-stimulation alone remarkably induced global level of H3K9ac compared to the control hMSCs (Figure 4A). Further, $1,25(\mathrm{OH})_{2} \mathrm{D}_{3}$ pretreatment followed by MRSA-stimulation did not affect the global level of H3K9ac compared to the MRSA-stimulation alone in hMSCs (Figure 4A). Similar with earlier report [45], MRSA-stimulation showed dramatic induction of Cox-2 protein (Figure 4A), NR4A2, VDR (Figures 1D-E, 3A iv, $3 \mathrm{~A}$ vi, and $4 \mathrm{~A}$ ) and $1,25(\mathrm{OH})_{2} \mathrm{D}_{3}$ pretreatment followed by MRSA-stimulation dramatically reduced Cox-2, NR4A2 protein levels in hMSCs (Figure 4A and Figure 3A iv).

5-deoxy-azacytidine (5-dAZA), an epigenetic drug that inhibits DNA methyltransferases (DNMTs) inhibits DNA methylation and often is used in vitro to induce the reexpression of genes putatively silenced by promoter methylation [46,47]. In order to test whether inhibiting methylation event with 5-dAZA, inhibits DNA methylation and histone methylation, as a result can re-express the $1,25(\mathrm{OH})_{2} \mathrm{D}_{3}$-MRSA-mediated silenced pro-inflammatory IL-8 gene. In order to demonstrate whether $1,25(\mathrm{OH})_{2} \mathrm{D}_{3}$ MRSA silencing cytokines expression is universal we have used human embryonic kidney cells, HEK293 cells for the D-AZA experiments. Interestingly, we found that in HEK293 cells, 5-dAZA treatment reduces DNA and histone methylation, enhances IL-8 gene expression, furthermore, it dramatically re-expresses the $1,25(\mathrm{OH})_{2} \mathrm{D}_{3}$ MRSA-mediated silenced IL-8 gene (Figure 4B i). Similar data also obtained in hMSCs (Figure $4 \mathrm{C}$ ii). Altogether, our data supporting the notion that $1,25(\mathrm{OH})_{2} \mathrm{D}_{3}$-activated VDR is an epigenetic regulator and may inhibits synthesis of cytokines in MRSA-stimulated infection by restoring the global level of $\mathrm{H} 3 \mathrm{~K} 9 \mathrm{me} 3$, a histone $\mathrm{H} 3$ mark for gene silencing.

\section{Discussion}

Human mesenchymal stem cells (hMSCs) are known to maintain regeneration of mesodermal tissue throughout the life time of an individual, which is dependent on the balance between the ability to differentiate into specialized cell types and self-renew. Excess self-renew and over differentiation may lead to mutation or tumorigenesis [25]. As hMSCs are also well known for their immunomodulatory functions, it is important to understand the factors playing role in the recognition of pathogens, which can lead to substantial changes in basic cellular functions. So far the only pathogen recognition receptors found in hMSCs are Toll like receptors (TLRs). Identification of TLR expression patterns which are associated with recognition of specific microbial molecules is critical to understand pathogen-host interactions. In our study, we used Staphylococcus (MRSA), a common pathogen of human body. Staphylococcus in particular; Staphylococcus aureus is the predominant cause of bone infections. Staphylococcal bone infections are thus increasing concern and understanding of the interaction of these pathogens with the bone is central to the development of the novel therapeutic strategies required to treat increasing antibiotic resistant and persistent infections. Our study revealed that expression levels of TLR3, TLR4 and TLR5 


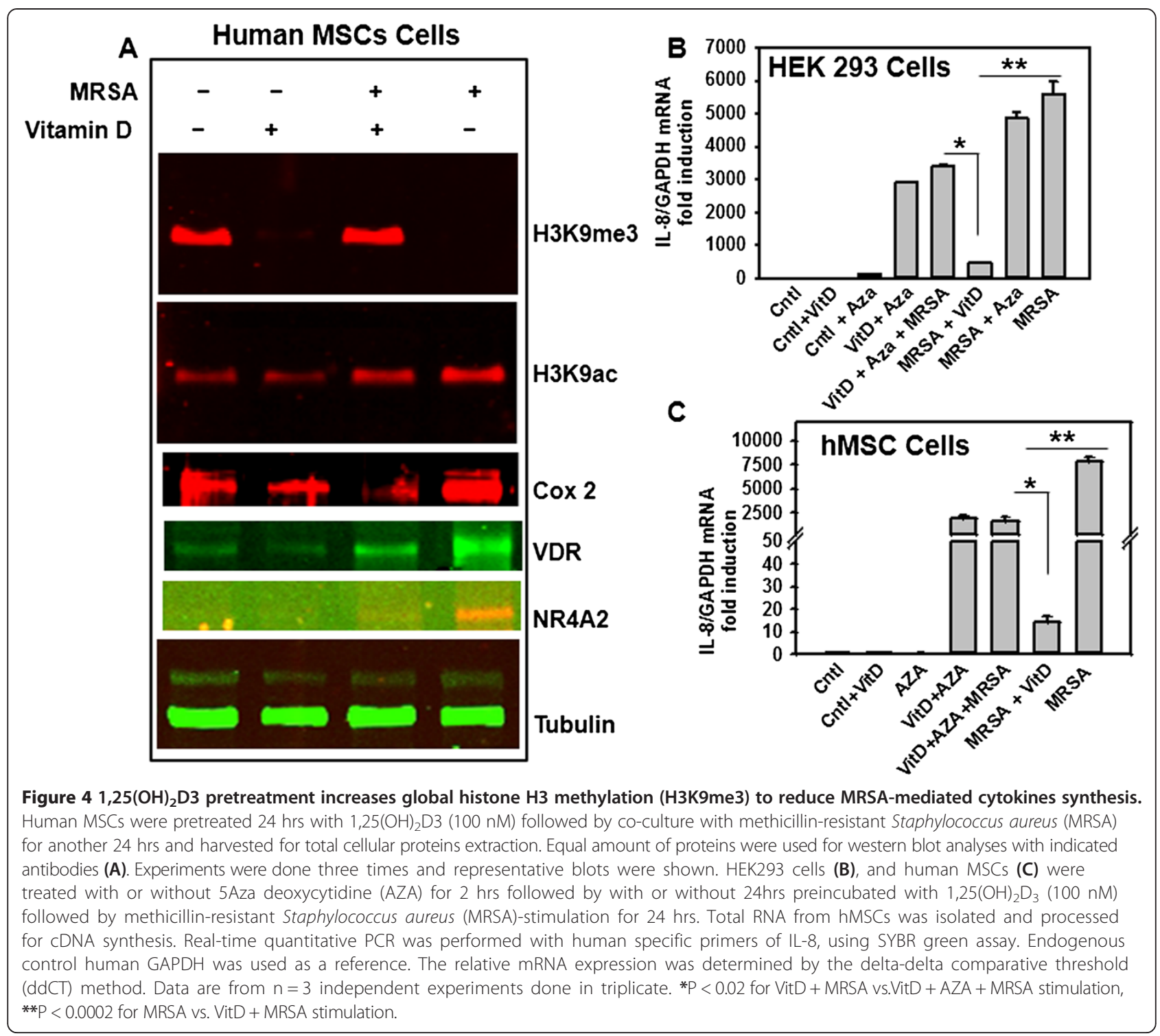

mRNAs in control hMSCs (without co-culture with live bacteria) were consistently high. By contrast, low expression level of TLR1, TLR2 and TLR6 and no expression of TLR 7, TLR 8, and TLR 9 were detected in control hMSCs, similar with the results obtained by Liotta et al. [19]. Further confirmation of TLR response with validated human specific qPCR primers of TLRs revealed that in response to co-culture with live MRSA increased mRNA expression of TLR 1, 2, and 6 in hMSCs. In addition to inflammatory responses, TLRs have been shown to directly regulate cell survival and cellular proliferation in a variety of biological settings [48]. The TLRs which are found to express in control cells, are may be involved for normal cell survival and proliferation. In agreement, as reported earlier by Bandow et al. [49], we have shown that activation of TLRs in response to MRSA co-culture completely suppressed osteoblast differentiation and increased cell proliferation. Increased IL-8 and NR4A2 are associated with inflammatory arthritis [22,50,51]. NR4A2 sub family has emerged as potential regulators of cytokines and growth factor action through regulating the inflammatory response underlying several diseases. NR4A2 is rapidly and potentially induced by a range of cytokines, suggesting that these receptors act as potential transcriptional mediators of inflammatory signals [22,51-53]. We have tested several inflammatory genes expression in MRSA-mediated infection condition in hMSCs. We found that when hMSCs were co-culture with MRSA resulted in up regulation of IL-8, IL-6, TNF $\alpha$, NR4A2, VDR, and OPN transcripts. Osteopontin (OPN) is expressed by several tissues, regulated by several signaling pathways and transcription factors that are associated with cancer progression [54]. 
Within bone tissue OPN plays a key role in cell adhesion, migration and survival. As IL- 8 is the target gene for NR4A2, our data support the notion that NR4A2 could be a critical regulator of those gene involved in proliferation in infection-mediated TLR-activated hMSCs. Interestingly, we found that VDR expression is very high after treating hMSCs with MRSA. In our study we observed that hMSCs without any MRSA infection form distinct nodules and exhibited ALP activity and de novo formation of extracellular calcium deposition (Figure 1F), which is consistent with the previous observations found in control murine MSCs [25,55]. However, MRSA infection fully blocked extracellular calcium deposition and ALP staining (Figure 1F-G), while it promotes hMSCs proliferation (Figure 1G-H). This indicated clearly a shift of hMSCs to self-renewal rather differentiation due to extracellular MRSA infection.

In immune cells, TLRs ligands activate downstream signaling and translocate NF-kB-p65, a key transcription factor, to the nucleus for synthesis of its target genes include inflammatory cytokines IL-8, IL-6, and TNF $\alpha$ [26]. Recently, it has been implicated in human inflammatory joint disease; nuclear protein NR4A2 cooperatively interacted with NF-kB-p65 at the IL-8 promoter for its transcriptional activation with TNF $\alpha$ [22]. It has long been known that $1,25(\mathrm{OH})_{2} \mathrm{D}_{3}$ exert its anti-inflammatory effect by inhibiting NF-kB-p65 activity. Therefore, 1,25 $(\mathrm{OH})_{2} \mathrm{D}_{3}$ suppression of NF-kB activation has great biological and pathological relevance. However, it remains to be determined how vitamin D receptor (VDR) is directly involved in the regulation of the NF- $\mathrm{kB}$ pathway. Chen et al. [56], reported that VDR physically interact with IkB kinase to block NF- $\mathrm{B}$ activation. In dendritic cells, $1,25(\mathrm{OH})_{2} \mathrm{D}_{3}$ inhibits IL-12 expression through targeting the NFKB pathway [57]; by directly suppresses RelB transcription [58]. In addition, it was reported that epigenetic regulation is essential to NF-kB-p65 transcriptional activity via lysine methylation $[59,60]$. We also found that pretreatment of hMSCs with 1,25(OH) 2D3 followed by MRSA stimulation significantly blocked NF-kB-p65 nuclear translocation and inflammatory cytokines synthesis. Further, NF-kB-p65, VDR and NR4A2 were present in the same nuclear protein complex, indicating that VDR is an active part of the nuclear protein complexes for transcriptional regulation.

The actions of $1,25(\mathrm{OH})_{2} \mathrm{D}_{3}$ are mediated by the VDR, a transcription factor that belongs to nuclear hormone receptor superfamily [61]. Previous research showed that binding of $1,25(\mathrm{OH})_{2} \mathrm{D}_{3}$ to VDR in the cytoplasm of cells stimulates heterodimerization of VDR with RXR and the redistribution of the VDR-RXR-hormone complex to the nucleus $[62-65,17,18]$. Recently, it has been reported that VDR and many other nuclear receptors such as NR4A2 interacts with coactivators and corepressors during the transcriptional cycle [18]. Saijo et al. [66] has reported the involvement of NR4A2-CoREST corepressor complex signaling pathway in neuro-inflammation, which further explain the regulatory role of VDR-NF-kB-NR4A2 in inflammation.

The VDR, such as many other nuclear receptors, interacts with coactivators and corepressors during the transcriptional cycle $[18,66]$ has reported recently, anti-inflammatory role of NR4A2-CoREST corepressor complex signaling pathway in neuro-inflammation, which further the regulatory role of VDR-NF-kB-NR4A2 in inflammation. Several related recent observations revealed that VDR-corepressor complexes could also repress transcription of genes in a ligand-dependent manner through epigenetic modification of DNA Methylation and histone methylation in the gene promoter regions [67-69]. Binding of NCOR1 at a specific VDR binding site was associated with the loss of H3K9ac and gain of H3K9me2 and H3K27me3 [18]. Methylation of lysines $\mathrm{H} 3 \mathrm{~K} 9$ and $\mathrm{H} 3 \mathrm{~K} 27$ is correlated with transcriptional repression [41], particularly; H3K9me3 is highly correlated with constitutive heterochromatin [42], associated with CpG methylation [70,71], a histone mark for transcription repression. Given that H3K9me levels can attract the machinery that drives DNA CpG methylation, we test whether inhibiting methylation event with 5dAZA, inhibits DNA methylation and histone methylation can re-express the $1,25(\mathrm{OH})_{2} \mathrm{D}_{3}$-MRSA-mediated silenced inflammatory gene. Our data indicated for the first time that $1,25(\mathrm{OH})_{2} \mathrm{D}_{3}$ pre-treatment followed by MRSA treatment restored H3K9me3 levels, and blocked synthesis of cytokines. In addition, 5-dAZA treatment reduces DNA and histone methylation, enhances IL-8 gene expression, furthermore, it dramatically re-expresses the $1,25(\mathrm{OH})_{2} \mathrm{D}_{3}$-MRSA-mediated silenced IL-8 gene (Figure 4). Our study revealed an interrelated set of factors that explain the epigenetic mechanism of ligand bound VDR to inhibit the synthesis of cytokines. It is tempted to speculate that $1,25(\mathrm{OH})_{2} \mathrm{D}_{3}$-VDR-NR4A2 mediated global epigenetic mechanisms may directly regulate NF-kB-p65 translocation to the nucleus and epigenetically modulate targeted cytokine promoters for transcriptional inhibition. However further confirmation is required by detail studies whether VDR mediated epigenetic modification is on global transcription factors on cytokine promoters or NF-kB-p65 chaperoned by VDR and NR4A2 recruitment to the targeted gene promoters.

\section{Conclusions}

Altogether, our data explain that TLR 1, 2, and 6 can be used as markers for localized Staphylococcus bone infection and supporting the notion that $1,25(\mathrm{OH})_{2} \mathrm{D}_{3}$ has potential role in inhibition of methicillin-resistant Staphylococcus aureus (MRSA)-stimulated infection mediated inflammation by inhibiting IL-8, IL-6, TNF- $\alpha$ and 
NR4A2 transcripts in hMSCs. $1,25(\mathrm{OH})_{2} \mathrm{D}_{3}$ inhibits translocation of NF-kB-p65, an important transcription factor for inflammation, to the nucleus, indicating its anti-inflammatory role in hMSCs. Further, we also partly demonstrated that $1,25(\mathrm{OH})_{2} \mathrm{D}_{3-} \mathrm{VDR}$ is an epigenetic regulator and may exhibit its anti-inflammatory properties by restoring transcription repression histone methylation mark (such as H3K9me3). 1,25(OH) ${ }_{2} \mathrm{D}_{3}$ may inhibit synthesis of cytokines by restoring histone methylation at the gene promoters. Further studies are required to elucidate the mechanism of $1,25(\mathrm{OH})_{2} \mathrm{D}_{3}$-activated VDR epigenetic mechanism inhibited synthesis of cytokines in MRSA-stimulated infection by restoring the global level of H3K9me3, a histone H3 mark for gene silencing.

\section{Methods}

Bone marrow aspiration and mesenchymal stem cells (hMSCs) isolation and culture

Fresh bone marrow was obtained by aspiration $(5-10 \mathrm{ml}$ aspirate) from proximal femur of patients undergoing primary hip arthroplasty. The mean age was 55 y (range 50-70 y). The study protocol was approved by the Ethics Committee, Institutional Review Board (IRB) of Virginia Commonwealth University, Medical Center, Richmond, Virginia, USA. Human Bone marrow derived Mesenchymal stem cells (hMSCs) were isolated from adult human bone marrow samples by the adherence method [72]. Briefly, the mononuclear cell fraction was isolated from red blood cells by density gradient centrifugation over histopaque 1077 (Sigma-Aldrich, St Louis MO). Isolated mononuclear cells were added to a T75 tissue culture flask containing DMEM high glucose medium supplemented with $10 \%$ FBS, $1 \%$ antibiotics (penicillin and streptomycin) and $2 \mathrm{ng} / \mathrm{ml}$ basic-FGF. Non-adherent cells were removed after 4 days and homogenous adherent cells (hMSCs) were expanded in the same medium.

\section{In vitro co-culture of hMSCs and S. aureus (MRSA)}

Adherent hMSC cells were washed twice in PBS and resuspended in antibiotic-free medium (DMEM $+10 \%$ FBS $+2 \mathrm{ng} / \mathrm{ml}$ basic-FGF) at a density of 75,000 cell $/ \mathrm{ml}$ and plated in 6-well tissue Plates. S. aureus (MRSA) (strain 2884D) (kindly gifted by Sam Boundy, Ph.D, Department of Internal Medicine, Division of Infectious Diseases, Virginia Commonwealth University School of Medicine) were grown overnight in Tryptocase Soy Broth (TSB) (Sigma, USA) in shaking conditions at $37^{\circ} \mathrm{C}$ until they reached an optical density of 1.0 , pelleted cells washed twice in PBS and added to cells at a multiplicity of infection (MOI) of 1:100 for a set time period mentioned in each figures [73]. The MSCs were then washed with sterile PBS and used for proteins and RNA isolation.

\section{RNA extraction and real-time quantitative PCR}

Human MSCs total RNA was isolated using Trizol reagent (Invitrogen Life Technologies, USA). Contamination of DNA was removed using DNase I treatment (Promega, USA). Equal amount of RNA $(1 \mu \mathrm{g})$ was used for cDNA synthesis using the iSCRIPT cDNA synthesis kit (Bio-Rad, USA). All PCR products were visualized by ethidium bromide after $1 \%$ agarose gel electrophoresis. Human specific RT-PCR primers sequences of TLRs 1-9, IL-6, IL-8, NR4A2, VDR, and OPN, GAPDH as an endogenous housekeeping gene control used for this study were described before [22,74-76].

All semi quantitative RT-PCR data including TLRs expression in MSCs were again confirmed with human specific primers for qPCR using SYBR green assay. All the qPCR primers including human TLRs primers were obtained from online PrimerBank public resources (http://pga.mgh.harvard.edu/primerbank/index.html). The sequences of the qPCR primers were: hTLR1: $\left(5^{\prime} \rightarrow 3^{\prime}\right)$ Forward TGAACCTCAAGCACTTGGACC and Reverse CCCATAA GTCTCTCCTAAGACCA; hTLR2: $\left(5^{\prime} \rightarrow 3^{\prime}\right)$ Forward TCCAGCA CACGAA TACA CAGT and Reverse AGGCATCTGGTAGAGTCATCAA; hTLR3: $\left(5^{\prime} \rightarrow 3^{\prime}\right)$ Forward TTGCCTTGTATCTACTTTTGGGG and Reverse TCAACACTGTTATGTTT GTGGGT; hTLR4: $\left(5^{\prime} \rightarrow 3^{\prime}\right)$ Forward GTACCTGGGGAACAACCTCTT and Reverse GCAGCTTGACTAGACTCTCCA; hTLR5: $\left(5^{\prime} \rightarrow 3^{\prime}\right)$ Forward TCCCTGA ACTCACGAGTCTTT and Reverse GGTTGTCAAGTCCGTAAAATGC; hTLR6: $\left(5^{\prime} \rightarrow 3^{\prime}\right)$ Forward TTCTCCGACGGAAATGAATTTGC and Reverse CAGC GGTA GGTCTTTTGGAAC; hTLR7: $\left(5^{\prime} \rightarrow 3^{\prime}\right)$ Forward TCCTTGGGGCTAG ATGG TTTC and Reverse TCCACGATCACATGGTTCTTTG; TLR8: $\left(5^{\prime} \rightarrow 3^{\prime}\right)$ Forward TGTGAG TTATGCGCCGAAGAA and Reverse GTTTGGGGAACTTCCTGTAGTC; hTLR9: $\left(5^{\prime} \rightarrow 3^{\prime}\right)$ Forward CTGCCACATGACCATCGAG Reverse GGACAGG GATAT GAGGGATTTGG; hTLR10: $\left(5^{\prime} \rightarrow 3^{\prime}\right)$ Forward GATTTACTCTGGGACGACCTTTT and Reverse GTCAAGATAAGCCTTACCACCAA; hNR4A2: $\left(5^{\prime} \rightarrow 3^{\prime}\right)$ Forward AGAGCTACAGTTACCACTCTTCG and Reverse GAGGTCCATGCTAA ACTTGACAA; hVDR: $\left(5^{\prime} \rightarrow 3^{\prime}\right)$ Forward TCTCCAATCTGGATCT GAGTGAA and Reverse ACAGCTCTAGGGTCACA GAAG; hIL-8: $\left(5^{\prime} \rightarrow 3^{\prime}\right)$ Forward AGG TGC AGT TTT GCC AAG GA and Reverse TTT CTG TGT TGG CGC AGT GT; hIL-6: $\left(5^{\prime} \rightarrow 3^{\prime}\right)$ Forward GAG GCA CTG GCA GAA AAC AA and Reverse TGG CAT TTG TGG TTG GGT CA; hOPN: $\left(5^{\prime} \rightarrow 3^{\prime}\right)$ Forward ATCCATGTGG TCATGGCTTT and Reverse GAAGGAGCTGAAGGA GCTGA; hTNF- $\alpha\left(5^{\prime} \rightarrow 3^{\prime}\right)$ Forward AGCCCATGTTG TAGCAAACC and Reverse TGAGGTACAGGCCCTCT GAT; hGAPDH: $\left(5^{\prime} \rightarrow 3^{\prime}\right)$ Forward AAGGTGAAGGTCG GAGTCAAC and Reverse GGGGTCATTGATGGCAA CAATA. Quantitative RT-PCR was performed using a 
SYBR ${ }^{\circ}$ Green I kit (Bio-Rad, USA) in a CFX96 Real-Time PCR Detection System (Bio-Rad, USA) according to the manufacturer's instructions. The following cycling parameters were used: $5 \mathrm{~min}$ at $94^{\circ} \mathrm{C} ; 40$ cycles of $45 \mathrm{~s}$ at $94^{\circ} \mathrm{C}$, $45 \mathrm{~s}$ at $55^{\circ} \mathrm{C}$ and $1 \mathrm{~min}$ at $72^{\circ} \mathrm{C}$; and finally $10 \mathrm{~min}$ at $72^{\circ} \mathrm{C}$, followed by a final dissociation stage. Fold change of TLRs mRNA levels were calculated based on the threshold cycle (CT) values and normalized to levels of constitutively expressed housekeeping gene Glyceraldehyde 3-phosphate dehydrogenase (GAPDH) mRNA. The comparative CT method with the formula $2^{-\Delta \Delta C t}$ was used to analyze the data. The formula used to calculate $\Delta \mathrm{CT}=\mathrm{Avg} \cdot \mathrm{TLR}$ CT - Avg.GAPDH CT. All reactions were replicated. Melting curve analysis showed accurate PCR performance with a single peak without any nonspecific products for both populations. We used in vitro cultured hMSCs without any bacterial inoculation as our control treatment. Three independent PCR runs were performed with MSCs isolated from three independent donors to check consistency of the TLR expression in control cells, before doing S. aureus infection as a treatment.

\section{Nuclear and cellular extract preparation, western blotting, and immunoprecipitation}

Human MSC cells were rinsed twice in ice-cold PBS. Cell pellets were used to isolate nuclear and cytoplasmic fractions using NE-PER Nuclear and Cytoplasmic Extraction kit (Pierce, USA). For other experiments, cell pellets were resuspended in the extraction buffer [10 mM TrisHCl, pH 7.5; $50 \mathrm{mM} \mathrm{NaCl}$; $0.1 \mathrm{mM}$ EDTA; 0.5\% Triton X-100; $40 \mathrm{mM} \mathrm{NaF;} 1 \mathrm{mM} \beta$-glycophosphate; and 1:500 protease inhibitor cocktail (Sigma, USA)] and sonicated with the probe sonicator (Fisher, USA) setting at 3 for 10 seconds $\times 3$ with 1 min interval on ice to make whole cell lysate. The cell lysates were centrifuged at 10,000 rpm for $10 \mathrm{~min}$ to obtain cell free extract for western blot analysis. Protein concentrations were measured (Bio-Rad protein assay) and stored at $-80^{\circ} \mathrm{C}$. Equal amounts of protein were separated by sodium dodecyl sulfate-polyacrylamide gel electrophoresis (SDS-PAGE), transferred to nitrocellulose, and immunoblotted with primary antibodies, anti-TLR1,2, Cyclin D1, Cox-2, Lamin A/C (Cell Signaling Technology, Inc. USA); H3K9me3, and H3K9ac (Abcam, USA); VDR, p65, NR4A2 (Santa Cruz Biotechnology, Inc. USA); Tubulin (Sigma, USA) and protein bands were detected using a Li-Cor Odyssey Infrared Scanner. For immunoprecipitation (IP) experiment, approximately $500 \mu \mathrm{g}$ nuclear proteins were pre-cleaned with protein A/G beads (Santa Cruz Biotechnology, Inc. USA) for $1 \mathrm{~h}$ at $4^{\circ} \mathrm{C}$ with agitation with the IP buffer $[10 \mathrm{mM}$ TrisHCl, pH 7.5; $150 \mathrm{mM} \mathrm{NaCl} ; 10 \%$ glycerol, $0.5 \%$ Triton X-100 (Sigma, USA)]. Protein A/G beads were pellet down at $3000 \mathrm{rpm}$ for $4 \mathrm{~min} 4^{\circ} \mathrm{C}$ and discarded. Anti-p65 antibodies were used over night to immunoprecipitate p65.
Finally, protein $\mathrm{A} / \mathrm{G}$ beads were used to capture immune complexes. Beads were washed extensively with the IP buffer and processed for western blot analysis.

\section{Osteogenic differentiation of hMSCs}

MSCs were continuously infected with live MRSA during osteogenesis to maintain the bacterial infected condition. Osteogenic differentiation of MSCs was performed in DMEM medium containing 10\% FBS, 1\% pens/strep antibiotics, $10 \mathrm{mM}$ glycerol-2-phosphate disodium salt hydrate, $0.1 \mathrm{mg} / \mathrm{ml}$ ascorbic acid and $0.1 \mu \mathrm{M}$ Dexamethasone (Dex) (Sigma-Aldrich). All experiments were done in triplicate in 6 well plates. Differentiation medium was replaced fresh at 3 day intervals from the start of the experiment.

\section{Alizarin red, alkaline phosphatase (ALP) and proliferation assay}

For alizarin Red and Alkaline phosphatase assay at day 14 and day 9 respectively, monolayers of MSCs were fixed with $4 \%$ para-formaldehyde for $10 \mathrm{~min}$ at room temperature, followed by washes with PBS several times and then stained for Alizarin Red S (aqueous 2\% Alizarin Red, $\mathrm{pH}$ 4.2; Sigma-Aldrich) or Alkaline phosphatase assay and washed several times with PBS to remove over staining. Alkaline phosphatase was stained from cell lysate as released p-nitrophenol from a Naphthol AS-MX phosphate substrate (Sigma- Aldrich) after 15 min of incubation at $37^{\circ} \mathrm{C}$. Proliferation assay was done with $1 \mu \mathrm{M}$ DRAQ5 [77] which stains DNA following manufacturer's protocol and scanned in Li-Cor Odyssey Infrared Scanner. Equal area scanned intensities were plotted against samples of different day of treatment.

\section{Statistical analysis}

Results are presented as means \pm SE. For statistical analysis, Student's unpaired t test for independent samples was used. A value of $\mathrm{P}<0.05$ was regarded as statistically significant. All analyses were performed using MS Office Excel 2013, and SigmaPlot12.0.

\section{Abbreviations}

TLRs: Toll like receptors; MRSA: Methicillin-Resistant Staphylococcus aureus; hMSCs: human mesenchymal stem cells; $1,25(\mathrm{OH})_{2} \mathrm{D}_{3}$ : 1,25-dihydroxyvitamin $D_{3}$; VDR: vitamin D receptor; IL-6: Interleukin-6; IL-8: interleukin-8; TNFa: tumor necrosis a; HDAC: Histone deacetylase; DNMT: DNA methyltransferase; CpG: Cytosine-phosphate-guanine.

\section{Competing interests}

The authors declare that they have no competing interests.

\section{Authors' contributions}

AM developed the concept, designed and carried out experiments. AM and WAJ analyzed data. AM created figures. AM, WAJ wrote the manuscript. Both authors read and approved the final manuscript.

\section{Acknowledgments}

We thank our colleagues in the Department of Orthopaedic surgery for their support. This research was funded by Department of Orthopaedic Surgery, Virginia Commonwealth University School of Medicine, USA (W.A.J). Partial

financial support was received from Medarva Healthcare, Richmond, Virginia, USA. 


\section{Author details}

${ }^{1}$ Department of Orthopaedic Surgery, Orthopaedic Research Laboratory, 1112 East Clay Street, Richmond, USA. ²Department of Orthopaedic Surgery, Virginia Commonwealth University School of Medicine, 1250 East Marshall Street, Richmond, VA 23298-0614, USA

Received: 30 December 2013 Accepted: 18 March 2014

Published: 25 March 2014

\section{References}

1. Berendt T, Byren I: Bone and joint infection. Clin Med 2004, 4(6):510-518.

2. Marriott I, Hughes FM Jr, Bost KL: Bacterial infection of osteoblasts induces interleukin-1 beta and interleukin-18 transcription but not protein synthesis. J Interferon Cytokine Res 2002, 22(10):1049-1055.

3. Marriott I: Osteoblast responses to bacterial pathogens: a previously unappreciated role for bone-forming cells in host defense and disease progression. Immunol Res 2004, 30(3):291-308.

4. Nemeth K, Mayer B, Mezey E: Modulation of bone marrow stromal cell functions in infectious diseases by toll-like receptor ligands. $J \mathrm{Mol}$ Med 2010, 88(1):5-10.

5. Hasan UA, Trinchieri G, Vlach J: Toll-like receptor signaling stimulates cell cycle entry and progression in fibroblasts. J Biol Chem 2005, 280(21):20620-20627.

6. Takeuchi O, Hoshino K, Kawai T, Sanjo H, Takada H, Ogawa T, Takeda K Akira S: Differential roles of TLR2 and TLR4 in recognition of gram-negative and gram-positive bacterial cell wall components. Immunity 1999, 11(4):443-451.

7. Rakoff-Nahoum S, Medzhitov R: Toll-like receptors and cancer. Nat Rev Cancer 2009, 9(1):57-63.

8. Liu PT, Krutzik SR, Modlin RL: Therapeutic implications of the TLR and VDR partnership. Trends Mol Med 2007, 13(3):117-124.

9. Liu PT, Schenk M, Walker VP, Dempsey PW, Kanchanapoomi M, Wheelwright M, Vazirnia A, Zhang X, Steinmeyer A, Zugel U, Hollis BW, Cheng G, Modlin RL: Convergence of IL-1 beta and VDR activation pathways in human TLR2/1-induced antimicrobial responses. PLOS One 2009 4(6):e5810.

10. Krutzik SR, Tan B, Li H, Ochoa MT, Liu PT, Sharfstein SE, Graeber TG, Sieling PA, Liu YJ, Rea TH, Bloom BR, Modlin RL: TLR activation triggers the rapid differentiation of monocytes into macrophages and dendritic cells. Nat Med 2005, 11(6):653-660

11. Zhang D, Zhang G, Hayden MS, Greenblatt MB, Bussey C, Flavell RA, Ghosh S: A toll-like receptor that prevents infection by uropathogenic bacteria. Science 2004, 303(5663):1522-1526.

12. Battersby AJ, Kampmann B, Burl S: Vitamin D in early childhood and the effect on immunity to Mycobacterium tuberculosis. Clin Dev Immunol 2012, 2012:430972

13. Wiedermann U, Tarkowski A, Bremell T, Hanson LA, Kahu H, Dahlgren UI: Vitamin A deficiency predisposes to Staphylococcus aureus infection. Infect Immun 1996, 64(1):209-214

14. Zwerina K, Baum W, Axmann R, Heiland GR, Distler JH, Smolen J, Hayer S, Zwerina J, Schett G: Vitamin D receptor regulates TNF-mediated arthritis. Ann Rheum Dis 2011, 70(6):1122-1129.

15. Liu PT, Stenger S, Li H, Wenzel L, Tan BH, Krutzik SR, Ochoa MT, Schauber J, Wu K, Meinken C, Kamen DL, Wagner M, Bals R, Steinmeyer A, Zugel U, Gallo RL, Eisenberg D, Hewison M, Hollis BW, Adams JS, Bloom BR, Modlin RL: Toll-like receptor triggering of a vitamin D-mediated human antimicrobial response. Science 2006, 311(5768):1770-1773.

16. Saramaki A, Banwell CM, Campbell MJ, Carlberg C: Regulation of the human p21(waf1/cip1) gene promoter via multiple binding sites for p53 and the vitamin D3 receptor. Nucleic Acids Res 2006, 34(2):543-554

17. Saramaki A, Diermeier S, Kellner R, Laitinen H, Vaisanen S, Carlberg C: Cyclical chromatin looping and transcription factor association on the regulatory regions of the p21 (CDKN1A) gene in response to 1alpha, 25-dihydroxyvitamin D3. J Biol Chem 2009, 284(12):8073-8082

18. Thorne $\mathrm{L}$, Maguire $\mathrm{O}$, Doig CL, Battaglia S, Fehr L, Sucheston LE, Heinaniemi M, O'Neill LP, McCabe CJ, Turner BM, Carlberg C, Campbell MJ: Epigenetic control of a VDR-governed feed-forward loop that regulates p21(waf1/cip1) expression and function in non-malignant prostate cells. Nucleic Acids Res 2011, 39(6):2045-2056.
19. Liotta F, Angeli R, Cosmi L, Fili L, Manuelli C, Frosali F, Mazzinghi B, Maggi L, Pasini A, Lisi V, Santarlasci V, Consoloni L, Angelotti ML, Romagnani P, Parronchi P, Krampera M, Maggi E, Romagnani S, Annunziato F: Toll-like receptors 3 and 4 are expressed by human bone marrow-derived mesenchymal stem cells and can inhibit their T-cell modulatory activity by impairing Notch signaling. Stem Cells 2008, 26(1):279-289.

20. Lee BC, Kim MS, Choi SH, Kim TS: Involvement of capsular polysaccharide via a TLR2/NF-kappaB pathway in Vibrio vulnificus-induced IL-8 secretion of human intestinal epithelial cells. Int J Mol Med 2010, 25(4):581-591.

21. Moynagh PN: TLR signalling and activation of IRFs: revisiting old friends from the NF-kappaB pathway. Trends Immunol 2005, 26(9):469-476.

22. Aherne CM, McMorrow J, Kane D, FitzGerald O, Mix KS, Murphy EP: Identification of NR4A2 as a transcriptional activator of IL-8 expression in human inflammatory arthritis. Mol Immunol 2009, 46(16):3345-3357.

23. Lammi J, Aarnisalo P: FGF-8 stimulates the expression of NR4A orphan nuclear receptors in osteoblasts. Mol Cell Endocrinol 2008, 295(1-2):87-93.

24. Kato S: The function of vitamin D receptor in vitamin D action. J Biochem 2000, 127(5):717-722.

25. Pevsner-Fischer M, Morad V, Cohen-Sfady M, Rousso-Noori L, Zanin-Zhorov A, Cohen S, Cohen IR, Zipori D: Toll-like receptors and their ligands control mesenchymal stem cell functions. Blood 2007, 109(4):1422-1432.

26. Hayden MS, Ghosh S: Shared principles in NF-kappaB signaling. Cell 2008, 132(3):344-362.

27. Sitcheran R, Cogswell PC, Baldwin AS Jr: NF-kappaB mediates inhibition of mesenchymal cell differentiation through a posttranscriptional gene silencing mechanism. Genes Dev 2003, 17(19):2368-2373.

28. Mutt SJ, Karhu T, Lehtonen S, Lehenkari P, Carlberg C, Saarnio J, Sebert S,

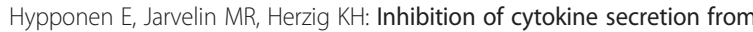
adipocytes by 1,25 -dihydroxyvitamin D3 via the NF-kappaB pathway. FASEB J 2012, 26(11):4400-4407.

29. D’Ambrosio D, Cippitelli M, Cocciolo MG, Mazzeo D, Di Lucia P, Lang R, Sinigaglia $F$, Panina-Bordignon $\mathrm{P}$ : Inhibition of $\mathrm{IL}-12$ production by 1,25-dihydroxyvitamin D3. Involvement of NF-kappaB downregulation in transcriptional repression of the p40 gene. J Clin Invest 1998, 101(1):252-262

30. Canning MO, Grotenhuis K, de Wit H, Ruwhof $\mathrm{C}$, Drexhage HA: 1-alpha, 25-Dihydroxyvitamin $\mathrm{D} 3(1,25(\mathrm{OH})(2) \mathrm{D}(3))$ hampers the maturation of fully active immature dendritic cells from monocytes. Eur J Endocrinol 2001, 145(3):351-357.

31. Tang $X$, Pan $Y$, Zhao $Y$ : Vitamin $D$ inhibits the expression of interleukin- 8 in human periodontal ligament cells stimulated with Porphyromonas gingivalis. Arch Oral Biol 2013, 58(4):397-407.

32. Martineau AR, Wilkinson KA, Newton SM, Floto RA, Norman AW, Skolimowska K, Davidson RN, Sorensen OE, Kampmann B, Griffiths CJ, Wilkinson RJ: IFN-gamma- and TNF-independent vitamin D-inducible human suppression of mycobacteria: the role of cathelicidin LL-37. J Immunol 2007, 178(11):7190-7198.

33. Peterson CA, Heffernan ME: Serum tumor necrosis factor-alpha concentrations are negatively correlated with serum $25(\mathrm{OH}) \mathrm{D}$ concentrations in healthy women. J Inflamm (Lond) 2008, 5:10.

34. Chambon P: A decade of molecular biology of retinoic acid receptors. FASEB J 1996, 10(9):940-954.

35. McKenna NJ, O'Malley BW: Combinatorial control of gene expression by nuclear receptors and coregulators. Cell 2002, 108(4):465-474.

36. Murayama A, Kim MS, Yanagisawa J, Takeyama K, Kato S: Transrepression by a liganded nuclear receptor via a bHLH activator through co-regulator switching. EMBO J 2004, 23(7):1598-1608.

37. Murayama A, Takeyama K, Kitanaka S, Kodera Y, Hosoya T, Kato S: The promoter of the human 25-hydroxyvitamin D3 1 alpha-hydroxylase gene confers positive and negative responsiveness to PTH, calcitonin, and 1 alpha,25(OH)2D3. Biochem Biophys Res Commun 1998, 249(1):11-16

38. Kim MS, Fujiki R, Kitagawa H, Kato S: 1alpha,25(OH)2D3-induced DNA methylation suppresses the human CYP27B1 gene. Mol Cell Endocrinol 2007, 265-266:168-173.

39. Jackson JP, Johnson $L$, Jasencakova $Z$, Zhang $X$, PerezBurgos $L$, Singh $P B$, Cheng X, Schubert I, Jenuwein T, Jacobsen SE: Dimethylation of histone $\mathrm{H} 3$ lysine 9 is a critical mark for DNA methylation and gene silencing in Arabidopsis thaliana. Chromosoma 2004, 112(6):308-315.

40. Lehnertz B, Ueda Y, Derijck AA, Braunschweig U, Perez-Burgos L, Kubicek S, Chen $T$, Li E, Jenuwein T, Peters AH: Suv39h-mediated histone H3 lysine 9 
methylation directs DNA methylation to major satellite repeats at pericentric heterochromatin. Curr Biol 2003, 13(14):1192-1200.

41. Rosenfeld JA, Wang Z, Schones DE, Zhao K, DeSalle R, Zhang MQ: Determination of enriched histone modifications in non-genic portions of the human genome. BMC Genomics 2009, 10:143.

42. Hublitz $\mathrm{P}$, Albert M, Peters $\mathrm{AH}$ : Mechanisms of transcriptional repression by histone lysine methylation. Int J Dev Biol 2009, 53(2-3):335-354.

43. Angrisano T, Pero R, Peluso S, Keller S, Sacchetti S, Bruni CB, Chiariotti L, Lembo F: LPS-induced IL-8 activation in human intestinal epithelial cells is accompanied by specific histone $\mathrm{H} 3$ acetylation and methylation changes. BMC Microbiol 2010, 10:172.

44. Kurdistani SK, Tavazoie S, Grunstein M: Mapping global histone acetylation patterns to gene expression. Cell 2004, 117(6):721-733.

45. Font-Nieves M, Sans-Fons MG, Gorina R, Bonfill-Teixidor E, Salas-Perdomo A, Marquez-Kisinousky L, Santalucia T, Planas AM: Induction of COX-2 enzyme and down-regulation of COX-1 expression by lipopolysaccharide (LPS) control prostaglandin E2 production in astrocytes. J Biol Chem 2012, 287(9):6454-6468.

46. Bender $\mathrm{CM}$, Zingg JM, Jones PA: DNA methylation as a target for drug design. Pharm Res 1998, 15(2):175-187.

47. Xiang N, Zhao R, Song G, Zhong W: Selenite reactivates silenced genes by modifying DNA methylation and histones in prostate cancer cells. Carcinogenesis 2008, 29(11):2175-2181

48. Li X, Jiang S, Tapping Rl: Toll-like receptor signaling in cell proliferation and survival. Cytokine 2010, 49(1):1-9.

49. Bandow K, Maeda A, Kakimoto K, Kusuyama J, Shamoto M, Ohnishi T, Matsuguchi T: Molecular mechanisms of the inhibitory effect of lipopolysaccharide (LPS) on osteoblast differentiation. Biochem Biophys Res Commun 2010, 402(4):755-761.

50. Bonta PI, van Tiel CM, Vos M, Pols TW, van Thienen JV, Ferreira V, Arkenbout EK, Seppen J, Spek CA, van der Poll T, Pannekoek H, de Vries CJ: Nuclear receptors Nur77, Nurr1, and NOR-1 expressed in atherosclerotic lesion macrophages reduce lipid loading and inflammatory responses. Arterioscler Thromb Vasc Biol 2006, 26(10):2288-2294.

51. Holla VR, Mann JR, Shi Q, DuBois RN: Prostaglandin E2 regulates the nuclear receptor NR4A2 in colorectal cancer. J Biol Chem 2006, 281(5):2676-2682.

52. Murphy EP, McEvoy A, Conneely OM, Bresnihan B, FitzGerald O: Involvement of the nuclear orphan receptor NURR1 in the regulation of corticotropin-releasing hormone expression and actions in human inflammatory arthritis. Arthritis Rheum 2001, 44(4):782-793.

53. Pei $L$, Castrillo A, Chen M, Hoffmann A, Tontonoz P: Induction of NR4A orphan nuclear receptor expression in macrophages in response to inflammatory stimuli. J Biol Chem 2005, 280(32):29256-29262.

54. El-Tanani M, Platt-Higgins A, Rudland PS, Campbell FC: Ets gene PEA3 cooperates with beta-catenin-Lef- 1 and c-Jun in regulation of osteopontin transcription. J Biol Chem 2004, 279(20):20794-20806.

55. Nemeth K, Keane-Myers A, Brown JM, Metcalfe DD, Gorham JD, Bundoc VG, Hodges MG, Jelinek I, Madala S, Karpati S, Mezey E: Bone marrow stromal cells use TGF-beta to suppress allergic responses in a mouse model of ragweed-induced asthma. Proc Natl Acad Sci U S A 2010, 107(12):5652-5657.

56. Chen Y, Liu W, Sun T, Huang Y, Wang Y, Deb DK, Yoon D, Kong J, Thadhani R, Li YC: 1,25-Dihydroxyvitamin $D$ promotes negative feedback regulation of TLR signaling via targeting microRNA-155-SOCS1 in macrophages. J Immunol 2013, 190(7):3687-3695.

57. Sun J, Kong J, Duan Y, Szeto FL, Liao A, Madara JL, Li YC: Increased NF-kappaB activity in fibroblasts lacking the vitamin D receptor. Am J Physiol Endocrinol Metab 2006, 291(2):E315-E322

58. Dong X, Craig T, Xing N, Bachman LA, Paya CV, Weih F, McKean DJ, Kumar R, Griffin MD: Direct transcriptional regulation of RelB by 1alpha,25-dihydroxyvitamin D3 20 and its analogs: physiologic and therapeutic implications for dendritic cell function. J Biol Chem 2003, 278(49):49378-49385.

59. Levy D, Kuo AJ, Chang Y, Schaefer U, Kitson C, Cheung P, Espejo A, Zee BM, Liu CL, Tangsombatvisit S, Tennen Rl, Kuo AY, Tanjing S, Cheung R, Chua KF, Utz PJ, Shi X, Prinjha RK, Lee K, Garcia BA, Bedford MT, Tarakhovsky A, Cheng X, Gozani O: Lysine methylation of the NF-kappaB subunit RelA by SETD6 couples activity of the histone methyltransferase GLP at chromatin to tonic repression of NF-kappaB signaling. Nat Immuno/ 2011, 12(1):29-36.
60. Lu T, Yang M, Huang DB, Wei H, Ozer GH, Ghosh G, Stark GR: Role of lysine methylation of NF-kappaB in differential gene regulation. Proc Natl Acad Sci U S A 2013, 110(33):13510-13515.

61. Haussler MR, Whitfield GK, Haussler CA, Hsieh JC, Thompson PD, Selznick $\mathrm{SH}$, Dominguez CE, Jurutka PW: The nuclear vitamin D receptor: biological and molecular regulatory properties revealed. J Bone Miner Res 1998, 13(3):325-349.

62. Barsony J, Pike JW, DeLuca HF, Marx SJ: Immunocytology with microwavefixed fibroblasts shows 1 alpha,25-dihydroxyvitamin D3-dependent rapid and estrogen-dependent slow reorganization of vitamin $D$ receptors. J Cell Biol 1990, 111(6 Pt 1):2385-2395.

63. Michigami T, Suga A, Yamazaki M, Shimizu C, Cai G, Okada S, Ozono K: Identification of amino acid sequence in the hinge region of human vitamin $D$ receptor that transfers a cytosolic protein to the nucleus. J Biol Chem 1999, 274(47):33531-33538.

64. Racz A, Barsony J: Hormone-dependent translocation of vitamin D receptors is linked to transactivation. J Biol Chem 1999, 274(27):19352-19360.

65. Sunn KL, Cock TA, Crofts LA, Eisman JA, Gardiner EM: Novel N-terminal variant of human VDR. Mol Endocrinol 2001, 15(9):1599-1609.

66. Saijo K, Winner B, Carson CT, Collier JG, Boyer L, Rosenfeld MG, Gage FH, Glass CK: A Nurr1/CoREST pathway in microglia and astrocytes protects dopaminergic neurons from inflammation-induced death. Cell 2009, 137(1):47-59.

67. Doig CL, Singh PK, Dhiman VK, Thorne JL, Battaglia S, Sobolewski M, Maguire O, O'Neill LP, Turner BM, McCabe CJ, Smiraglia DJ, Campbell MJ: Recruitment of NCOR1 to VDR target genes is enhanced in prostate cancer cells and associates with altered DNA methylation patterns. Carcinogenesis 2013, 34(2):248-256.

68. Kim JY, Son YL, Lee YC: Involvement of SMRT corepressor in transcriptional repression by the vitamin D receptor. Mol Endocrinol 2009, 23(2):251-264.

69. Fu B, Wang H, Wang J, Barouhas I, Liu W, Shuboy A, Bushinsky DA, Zhou D, Favus MJ: Epigenetic regulation of BMP2 by 1,25-dihydroxyvitamin D3 through DNA methylation and histone modification. PLOS One 2013, 8(4):e61423.

70. Mohn F, Schubeler D: Genetics and epigenetics: stability and plasticity during cellular differentiation. Trends Genet 2009, 25(3):129-136.

71. Fujita N, Watanabe S, Ichimura T, Tsuruzoe S, Shinkai Y, Tachibana M, Chiba T, Nakao M: Methyl-CpG binding domain 1 (MBD1) interacts with the Suv39h1-HP1 heterochromatic complex for DNA methylation-based transcriptional repression. J Biol Chem 2003, 278(26):24132-24138.

72. Pittenger MF: Mesenchymal stem cells from adult bone marrow. Methods Mol Biol 2008, 449:27-44

73. Lundequist A, Calounova G, Wensman H, Ronnberg E, Pejler G: Differential regulation of $\mathrm{Nr} 4 \mathrm{a}$ subfamily nuclear receptors following mast cell activation. Mol Immunol 2011, 48(15-16):1753-1761.

74. Krug A, Towarowski A, Britsch S, Rothenfusser S, Hornung V, Bals R, Giese T, Engelmann $H$, Endres $S$, Krieg AM, Hartmann G: Toll-like receptor expression reveals CPG DNA as a unique microbial stimulus for plasmacytoid dendritic cells which synergizes with CD40 ligand to induce high amounts of IL-12. Eur J Immunol 2001, 31(10):3026-3037.

75. Dubrovska A, Kim S, Salamone RJ, Walker JR, Maira SM, Garcia-Echeverria C, Schultz PG, Reddy VA: The role of PTEN/Akt/PI3K signaling in the maintenance and viability of prostate cancer stem-like cell populations. Proc Natl Acad Sci U S A 2009, 106(1):268-273.

76. Gavenis K, Andereya S, Schmidt-Rohlfing B, Mueller-Rath R, Silny J, Schneider U: Millicurrent stimulation of human articular chondrocytes cultivated in a collagen type-I gel and of human osteochondral explants. BMC Complement Altern Med 2010, 10:43.

77. Smith PJ, Wiltshire M, Errington RJ: DRAQ5 labeling of nuclear DNA in live and fixed cells. Curr Protoc Cytom 2004, Chapter 7. Unit 7.25.

doi:10.1186/1471-2121-15-11

Cite this article as: Maiti and Jiranek: Inhibition of Methicillin-resistant Staphylococcus aureus-induced cytokines mRNA production in human bone marrow derived mesenchymal stem cells by 1,25 -dihydroxyvitamin $D_{3}$. BMC Cell Biology 2014 15:11. 